\title{
First Report of Fenpyrazamine Resistance in Botrytis cinerea from Strawberry Fields in Spain
}

\begin{abstract}
Dolores Fernández-Ortuño, ${ }^{\dagger}$ Instituto de Hortofruticultura Subtropical y Mediterránea "La Mayora"-Universidad de Málaga-Consejo Superior de Investigaciones Científicas (IHSM-UMA-CSIC), Estación Experimental “La Mayora", 29750 Algarrobo-Costa (Málaga), Spain, and IHSM-UMACSIC, Dept. de Microbiología, Campus de Teatinos, 29071 Málaga, Spain; Alejandra Vielba-Fernández, IHSM-UMA-CSIC, Estación Experimental "La Mayora", 29750 Algarrobo-Costa (Málaga), Spain; Alejandro Pérez-García, IHSM-UMA-CSIC, Dept. de Microbiología, Campus de Teatinos, 29071 Málaga, Spain; Juan A. Torés, IHSM-UMA-CSIC, Estación Experimental "La Mayora", 29750 Algarrobo-Costa (Málaga), Spain; and Antonio de Vicente, IHSM-UMA-CSIC, Dept. de Microbiología, Campus de Teatinos, 29071 Málaga, Spain
\end{abstract}

Accepted for publication 29 January 2018.

Botrytis cinerea Pers. is an important fungal pathogen responsible for gray mold, one of the most economically important diseases of strawberry (Fragaria $\times$ ananassa) worldwide (Jarvis 1977). The primary disease management strategy involves the application of different classes of fungicides, including the sterol biosynthesis inhibitor (SBI) class III fungicide fenpyrazamine, an amino-pyrazolinone that was introduced in 2014 for managing gray mold in several crops, including cucurbits, eggplants, peppers, tomatoes, grapes, and strawberries in Spain. In 2014 and 2015, strawberries affected with gray mold symptoms were collected from eight locations (Almonte, Isla Cristina, Moguer, La Redondela, Lepe, Lucena del Puerto, Palos de la Frontera, and San Bartolome de la Torre) in Huelva, where the SBI class III hydroxyanilide fungicide fenhexamid (Teldor, Bayer Cropscience S.L.) had been used extensively over the last 7 years (Junta de Andalucía 2015). Twenty-five $B$. cinerea single-spore isolates, previously characterized for their sensitivity to fenhexamid (15 sensitive and 10 resistant; Fernández-Ortuño et al. 2016), were examined to determine the effective concentration that reduced mycelial growth by $50 \%\left(\mathrm{EC}_{50}\right)$ and to determine a discriminatory dose to monitor fenpyrazamine resistance in the field in future studies. In vitro sensitivity to fenpyrazamine (Prolectus, Kenogard, S.A.) was determined using a mycelial growth assay on 90-mm-diameter Petri dishes containing fungicide-amended (active ingredient concentrations: $0.25,0.5,1,2.5,5,10,25,50$, and $100 \mu \mathrm{g} / \mathrm{ml}$ ) or unamended $1 \%$ malt extract agar medium. The $\mathrm{EC}_{50}$ values were calculated as previously described (Fernández-Ortuño et al. 2017). The isolates were divided into two groups: 15 sensitive $\left(\mathrm{EC}_{50}\right.$ from 0.02 to $1.3 \mu \mathrm{g} / \mathrm{ml}$ ) and 10 resistant $\left(\mathrm{EC}_{50}\right.$ from 50.1 to $172.6 \mu \mathrm{g} / \mathrm{ml}$ ), which showed cross-resistance with fenhexamid. To assess the performance of fenpyrazamine in vivo, commercially grown strawberries, with unknown fungicide spray application history, were washed with water, dried, placed into plastic boxes (24 strawberry fruits per isolate divided into three 8-fruit replicates), and sprayed $3 \mathrm{~h}$ prior to inoculation with either water (control fruit) or $800 \mu \mathrm{g} / \mathrm{ml}$ of fenpyrazamine (label dose recommended for gray mold control on strawberry by the manufacturer). Then, the fruits were stab-wounded with a sterile syringe, inoculated with a $30-\mu l$ droplet of conidial suspension $\left(10^{6}\right.$ spores $\left./ \mathrm{ml}\right)$ of one of four isolates (two sensitive and two resistant), and kept at $22^{\circ} \mathrm{C}$ for 4 days under ambient light conditions. All four isolates caused visible symptoms of gray mold on inoculated control fruit (mean of $2.7-\mathrm{cm}$ lesion diameter), but only the fenpyrazamine-resistant isolates developed gray mold on the fungicide-treated fruit (mean of $2.0-\mathrm{cm}$ lesion diameter). The in vitro and in vivo experiments were performed twice. Based on the results, the discriminatory dose chosen to examine sensitivities in the field was $50 \mu \mathrm{g} / \mathrm{ml}$. This is the first report of fenpyrazamine resistance in $B$. cinerea from strawberry fields in Spain. To our knowledge, resistance to this active ingredient has only been reported in B. cinerea from strawberry in South Korea (Kim et al. 2016). The emergence of resistance to fenpyrazamine and crossresistance with fenhexamid emphasizes the importance of resistance management strategies, including rotating fungicides from different chemical classes or modes of action.

\section{Literature Cited}

Fernández-Ortuño, D., Pérez-García, A., Chamorro, M., de la Peña, E., de Vicente, A., and Torés, J. A. 2017. Resistance to the SDHI fungicides boscalid, fluopyram, fluxapyroxad, and penthiopyrad in Botrytis cinerea from commercial strawberry fields in Spain. Plant Dis. 101:1306-1313.

Fernández-Ortuño, D., Torés, J. A., Chamorro, M., Pérez-García, A., and de Vicente, A. 2016. Characterization of resistance to six chemical classes of site-specific fungicides registered for gray mold control on strawberry in Spain. Plant Dis. 100:2234-2239.

Jarvis, W. R. 1977. Botryiotinia and Botrytis Species: Taxonomy, Physiology, and Pathogenicity. Monograph Number 15. Research Branch Canada Department of Agriculture, Harrow, Ontario.

Junta de Andalucía. 2015. Balance fitosanitario del cultivo de la fresa campaña 2014-2015. Red de alerta e información fitosanitaria R.A.I.F. Consejería de Agricultura, Pesca y Desarrollo Rural. Online publication. Junta de Andalucía, Seville, Spain. http://www.juntadeandalucia.es/agriculturaypesca/ portal/export/sites/default/comun/galerias/galeriaDescargas/minisites/raif/ balances/2015/huelva/Informe_EspecialInteres_Fresa.pdf

Kim, J.-O., Shin, J.-H., Gumilang, A., Chung, K., Choi, K. Y., and Kim, K. S. 2016. Effectiveness of different classes of fungicides on Botrytis cinerea causing gray mold on fruit and vegetables. Plant Pathol. J. 32:570-574.

${ }^{\dagger}$ Corresponding author: Dolores Fernández-Ortuño;

E-mail: dfernandez-ortuno@uma.es

Funding: Funding was provided by Proyecto ComFuturo.

(C) 2018 The American Phytopathological Society 